\title{
PREVALENCE AND DISTRIBUTION OF CANINE NEOPLASTIC AND NON-NEOPLASTIC CUTANEOUS LESIONS IN SERBIA: A RETROSPECTIVE STUDY OF 2432 CASES (2011 - MID 2021)
}

\author{
Vladimir KUKOLJ*, Slađan NEŠIĆ, Darko MARINKOVIĆ, \\ Sanja ALEKSIĆ-KOVAČEVIĆ \\ Department of Pathology, Faculty of Veterinary Medicine, University of Belgrade, \\ Bulevar oslobodjenja 18, Belgrade, Serbia
}

(Received 08 October, Accepted 23 November 2021)

Cutaneous lesions, especially skin tumors in dogs, are among the most common lesions in this animal species. The aim of this study was to identify the most common types of canine cutaneous lesions, to determine the absolute and relative frequency of each type of cutaneous lesion, anatomical locations, mean age, as well as gender and breed distribution. The examination included all samples of cutaneous lesions in dogs obtained by surgical biopsy in veterinary clinics and examined at the Laboratory of the Department of Pathology at the Faculty of Veterinary Medicine, University of Belgrade from the $1^{\text {st }}$ January 2011 to the $1^{\text {st }}$ July 2021. In this period (126 months), a total of 2432 samples of cutaneous lesions were examined, of which 1984 (81.58\%) were tumors $(1037 / 1984,52.27 \%$ benign and $947 / 1984,47.73 \%$ malignant) and 448 $(18.42 \%)$ non-neoplastic cutaneous lesions. The most commonly found cutaneous tumors were: mast cell tumor (17.34\% of all tumors), histiocytoma (9.78\%), papilloma (7.91\%), lipoma (7.81\%), squamous cell carcinoma (7.36\%), trichoblastoma (4.44\%), hepatoid adenoma $(4.39 \%)$ and malignant melanoma $(4.18 \%)$. The most common non-neoplastic cutaneous lesions were: follicular cyst(s) $(35.04 \%$ of all non-neoplastic lesions), pyogranulomatous chronic dermatitis (23.88\%), lymphocytic dermatitis $(7.37 \%)$, hyperkeratosis $(4.24 \%)$, and granulomatous dermatitis $(3.79 \%)$. Our results substantially confirm previously reported data regarding cutaneous neoplastic and nonneoplastic lesions in dogs, and provide updated information on their frequency, animal age, anatomic location and breed distributions.

Keywords: cutaneous lesions, dog, neoplasm distribution, retrospective analysis, skin tumors.

\section{INTRODUCTION}

Canine neoplastic and non-neoplastic cutaneous lesions are quite common and have a similar clinical manifestation or macroscopic appearance, so it is very important to

\footnotetext{
*Corresponding author: e-mail: vkukolj@vet.bg.ac.rs
} 
make a correct diagnosis. Valid classification of cutaneous lesions is a prerequisite for appropriate therapy and adequate prognosis [1]. Several studies reported that cutaneous neoplasms made up almost half of all diagnosed tumors in dogs [2,3], while in other they ranked second only to mammary gland tumors and made up a third of all diagnosed tumors in this animal species [4].

Retrospective studies conducted in different geographical regions show the occurrence of cutaneous neoplasms of different types and relative frequency. According to the study on neoplastic and non-neoplastic cutaneous lesions in dogs in Grenada, West Indies, the most common types of cutaneous neoplasms in dogs are: hemangiosarcomas, histiocytomas, melanocytomas and mast cell tumors, which most frequently occur in local mixed-breeds, and the most numerous cutaneous non-neoplastic lesions were: sebaceous hyperplasia, fibroepithelial polyps and collagenous hamartomas [5]. In addition, the most common cutaneous neoplasms in dogs in Greece were mast cell tumors, hepatoid gland adenomas, lipomas and histiocytomas, localized on the head, neck, trunk and limbs [6]. The results of the study from Japan show that soft tissue sarcoma, mast cell tumor, lipoma and hair follicle tumor outnumbered the other tumor types. These cutaneous neoplasms were commonly found on the head, hind limb, forelimb, chest, and neck, especially in mixed-breed dogs, Miniature Dachshund, and Labrador Retriever [7]. Mast cell tumor and lipoma are the most often diagnosed tumors in dogs in Brazil, and epidermal inclusion cyst and trichogranuloma are the most frequent non-neoplastic lesions [8]. In some cases, mast cell tumor and lipoma were diagnosed in the same animal [9]. Retrospective study conducted in Korea pointed out that the most common tumors in dogs are lipomas, mast cell tumors, cutaneous histiocytomas and basal cell tumors sampled from the trunk, head and neck, extremities, anal and perianal area, and tail [10]. According to the results of Graf et al. (2018) in dogs in Switzerland, mast cell tumors, lipomas, hair follicle tumors and histiocytomas were most commonly found in mixed-breed dogs, Giant Schnauzer, Standard Schnauzer, Magyar Vizsla and Rhodesian Ridgeback [11]. Mast cell tumor, histiocytoma, hemangiosarcoma and melanocytoma are the most common tumors in dogs in South Africa [12], while lipoma, adenoma, and mast cell tumor are commonly found in dogs in North America [13].

The reason for the different distribution of tumor types is not known, but it is assumed that climatic factors could play a significant role. Thus, the occurrence of certain types of cutaneous neoplasms, such as cutaneous hemangiosarcomas, squamous cell carcinomas and malignant melanomas, has been associated with high exposure to ultraviolet radiation of sunlight [14].

Some dog breeds are prone to different types of cutaneous neoplasms. Compared with other breeds, the appearance of mast cell tumors is more common in Boxers, Pugs, Staffordshire bull terriers, Boerboels and Labrador retrievers. Malignant tumors of the skin are more commonly found in Jack Russell terriers, Rottweilers, Pit bull terriers and Staffordshire bull terriers [12]. 
Certain types of skin lesions in dogs are age-related. It has been noticed that histiocytoma usually occurs in young dogs (age 2.97 years), and mast cell tumor in middle-aged dogs (age 7.68 years) [15]. The prevalence of cutaneous histiocytoma, papilloma and dermoid cyst is considerably higher until the age of two years [16], while squamous cell carcinoma is more often diagnosed in older dogs [17].

Considering all the above-mentioned differences in the prevalence of certain types of cutaneous neoplasms and non-neoplastic lesions, as well as the fact that the last study regarding the cutaneous neoplasm incidence in dogs in Serbia was conducted 16 years ago $[4,18]$, the aim of this study was to identify the most common types of canine cutaneous tumors and non-neoplastic lesions and to determine the absolute and relative frequency of each type of cutaneous lesion, anatomical locations, mean age, gender and breed distribution.

\section{MATERIAL AND METHODS}

Skin and subcutaneous tissue samples were obtained by surgical biopsy in Serbian veterinary clinics, from dogs with cutaneous masses resembling tumors. The study included all samples of cutaneous lesions examined in the Laboratory of the Department of Pathology at the Faculty of Veterinary Medicine, University of Belgrade from the $1^{\text {st }}$ January 2011 to the $1^{\text {st }}$ July 2021.

After removal, samples were immediately placed in 10\% buffered formalin and delivered to the laboratory. Along with the sample, a referral with the data about dog (breed, sex, age), tumor location (head, neck, back, chest, abdomen, forelimbs, hind limbs, anus and tail) and macroscopic characteristics of removed lesions has been delivered to the laboratory. Skin biopsies were routinely processed in an automatic tissue processor, embedded into paraffin and cut into sections 3-5 $\mu \mathrm{m}$ thick, then stained with hematoxylin-eosin, and later on, in case of suspicion of mast cell tumor, with toluidine-blue method, as well as immunohistochemistry in some cases.

Tumor diagnosis and classification were performed according to World Health Organization [19,20] and Goldschmidt et al. (2018) [21] criteria. Based on the diagnosis, the samples were classified into two groups: cutaneous tumors and non-neoplastic cutaneous lesions.

The obtained results were statistically analyzed using descriptive statistical parameters (arithmetic mean, minimum and maximum value). The share of individual tumor types was calculated by dividing the absolute number of samples with the same diagnosis by the total number of examined samples. Samples without data for the selected parameter are not included in the calculation. Statistical analysis of the obtained results was performed in Microsoft Excel 2016 software. 


\section{RESULTS}

Out of 5001 examined dogs' biopsy specimens, 2432 (48.63\%) were cutaneous lesions. From 2432 samples, 1984 (81.58\%) were cutaneous tumors, and 448 (18.42\%) were non-neoplastic cutaneous lesions (Figure 1). The average age of dogs with cutaneous lesions was 7.11 years (2 months - 18 years). However, age data for 40 dogs were not available. Cutaneous lesions were more often diagnosed in males (1377 samples, $56.62 \%)$ than in females (1054 samples, 43.34\%), while for one dog $(0.04 \%)$ gender data was missing. Cutaneous lesions were found in 125 different breeds of which onefifth $(488,20.07 \%)$ were mixed-breed dogs, 161 (6.62\%) were Labrador Retrievers, 138 (5.67\%) Golden Retrievers, 122 (5.02\%) American Staffordshire Terriers, and 95 $(3.91 \%)$ Bichons. Of the total number of samples, $15(0.62 \%)$ samples did not have breed data. Cutaneous lesions were most often localized on the skin of the head (487 samples, 20.02\%), then on the forelimb (360 samples, 14.80\%). Further, $300(12.34 \%)$ samples with cutaneous lesions were skin biopsies from the abdomen, $279(11.47 \%)$ skin biopsies from the hind limbs, $246(10.12 \%)$ from the chest, $211(8.68 \%)$ from the back, 167 (6.87\%) biopsies of skin near the anus, $157(6.46 \%)$ from the neck and 44 $(1.81 \%)$ from the tail, while in $181(7.44 \%)$ cases there were no data on the location of the removed lesion.

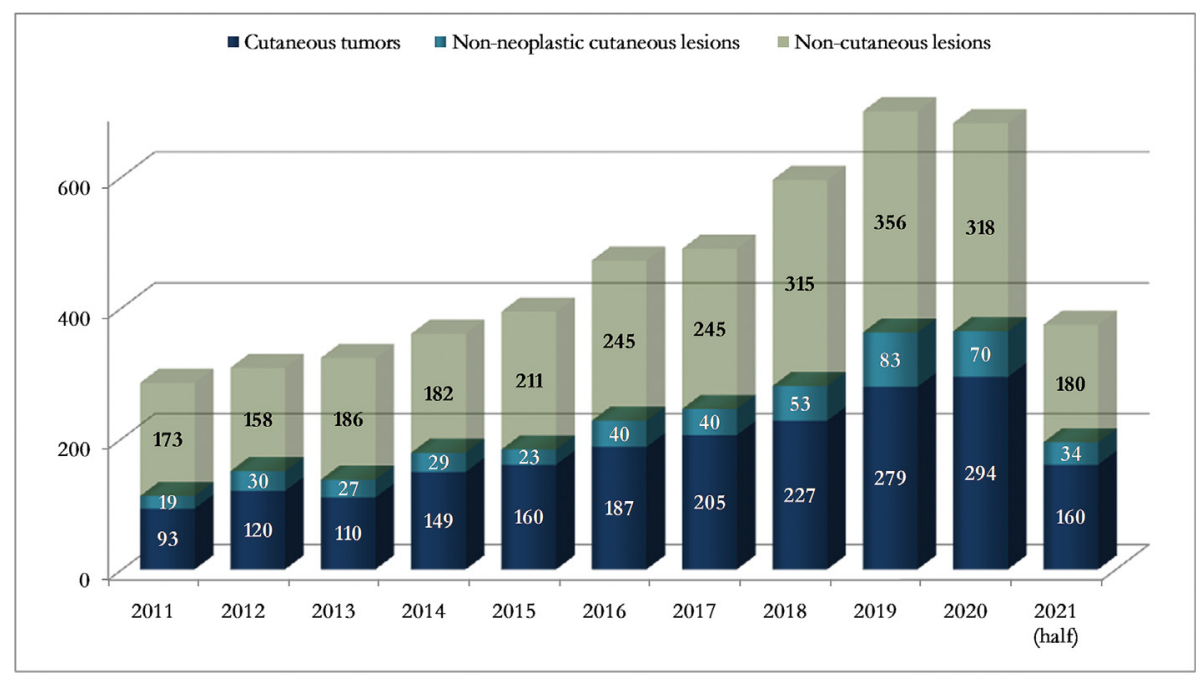

Figure 1. Number of cutaneous tumors, non-neoplastic cutaneous lesions and non-cutaneous lesions in the period $2011-\operatorname{mid} 2021$

\section{Cutaneous fumors}

In a total of 1984 diagnosed cutaneous tumors, 1037 (52.27\%) were benign, and the remaining 947 (47.73\%) were malignant. 
Data on the age of dogs with cutaneous tumors are shown in Table 1, except data for 30 dogs that were not available. Histiocytoma occurred in young dogs, so the average age of dogs with this cutaneous tumor was 2.32 years ( 6 months -13 years), compared to the average age of dogs with apocrine adenoma which was 12.00 years (11 years 13 years), and dogs with malignant trichoepithelioma 11.36 years (9 years -14 years).

Table 1. Mean age, minimal and maximal age for dogs with benign and malign cutaneous tumors

\begin{tabular}{ccccccccc}
\hline \multicolumn{2}{c}{$\begin{array}{c}\text { All cutaneous tumors } \\
(\mathrm{n}=\mathbf{1 9 5 4})\end{array}$} & \multicolumn{3}{c}{$\begin{array}{c}\text { Benign cutaneous tumors } \\
(\mathbf{n}=\mathbf{1 0 1 9})\end{array}$} & \multicolumn{2}{c}{$\begin{array}{c}\text { Malignant cutaneous tumors } \\
(\mathrm{n}=\mathbf{9 3 5})\end{array}$} \\
\hline Mean age & Minimal & Maximal & Mean age & Minimal & Maximal & Mean age & Minimal & Maximal \\
\hline $7.32 \mathrm{yrs}$ & 2 months & $18 \mathrm{yrs}$ & $6.66 \mathrm{yrs}$ & 2 months & $17 \mathrm{yrs}$ & $8.03 \mathrm{yrs}$ & 6 months & $18 \mathrm{yrs}$ \\
\hline
\end{tabular}

Cutaneous tumors were diagnosed in $1127(56.80 \%)$ males and $856(43.15 \%)$ females, and for one $(0.05 \%)$ dog there was no gender data. Out of 1037 samples of benign tumors, $593(57.18 \%)$ were from males, while $443(42.72 \%)$ samples were from females and for one $(0.10 \%)$ sample there was no data regarding gender. Of the 947 malignant tumors, $534(56.39 \%)$ were present in males, and the remaining $413(43.61 \%)$ obtained from females.

Cutaneous tumors were most often localized on the head (399 samples, 20.11\%), followed by the skin of the forelimbs in $290(14.62 \%)$ dogs. In $249(12.55 \%)$ cases tumors were on the skin of the abdomen, in $225(11,34 \%)$ on the skin of the hind limbs, while $205(10.33 \%)$ samples originated from the skin of the chest area. Further, $161(8.11 \%)$ dogs had a skin tumor in the area surrounding the anus, $150(7.56 \%)$ dogs had back skin tumors, $132(6.65 \%)$ dogs had a skin tumor on the neck and $35(1.76 \%)$ dogs were diagnosed with a skin tumor from the tail, while in $138(6.96 \%)$ cases data on the location were missing. Detailed data on the location of different groups of tumors are shown in Table 2. Out of 1037 benign tumors, the most common localization was in the head area (232 samples, 22.37\%), followed by the forelimbs with $145(13.98 \%)$ samples, $129(12.44 \%)$ samples of the skin of the abdomen and $112(10.80 \%)$ of the skin of the chest. In addition, $96(9.26 \%)$ samples were of skin near the anus, 94 $(9.06 \%)$ of the skin of the hind limbs, $78(7.52 \%)$ samples were from the back, 63 $(6.08 \%)$ from the neck and $17(1.64 \%)$ from the tail, and for 71 (6.85\%) samples there was no data on the tumor location. Samples of 947 malignant skin tumors originated most often from the head (167 samples, 17.63\%), 145 (15.31\%) of the skin of the forelimbs, $131(13.83 \%)$ were located on the skin of the hind limbs, $120(12.67 \%)$ on the skin of the abdomen, $93(9.82 \%)$ on the skin in the chest area, $72(7.60 \%)$ on the back, $69(7.29 \%)$ on the neck, $65(6.86 \%)$ in the area skin around the anus and 18 $(1.90 \%)$ on the tail, while for $67(7.07 \%)$ dogs tumor location data were not available.

In most cases, benign tumors were diagnosed in mixed-breeds (216 dogs, 20.83\%). Of the total number of dogs with benign tumors, 62 (5.98\%) dogs were Bichons, 
62 (5.98\%) Labrador Retrievers, 47 (4.53\%) American Staffordshire Terriers and 45 $(4.34 \%)$ Golden Retrievers. For $9(0.87 \%)$ dogs, there were no breed data. Similar to benign cutaneous tumors, malignant tumors were found in $182(19.22 \%)$ mixedbreed dogs, 77 (8.13\%) Labrador Retrievers, 76 (8.03\%) Golden Retrievers, 46 (4.86\%) American Staffordshire Terriers and 38 (4.01\%) Maltese, and for $6(0.63 \%)$ dogs with malignant tumors there were no data on the breed.

Table 2. Anatomical locations of different groups of cutaneous tumors

\begin{tabular}{|c|c|c|c|c|c|c|c|c|c|c|}
\hline \multirow{2}{*}{$\begin{array}{l}\text { Group of } \\
\text { cutaneous } \\
\text { tumors }\end{array}$} & \multicolumn{10}{|c|}{$\begin{array}{c}\text { Anatomical location } \\
n(\%)\end{array}$} \\
\hline & Head & Neck & Back & Chest & $\begin{array}{l}\text { Abdo- } \\
\text { men }\end{array}$ & $\begin{array}{l}\text { Fore- } \\
\text { limbs }\end{array}$ & $\begin{array}{l}\text { Hind } \\
\text { limbs }\end{array}$ & Anus & Tail & NA \\
\hline $\begin{array}{l}\text { Epithelial } \\
\text { tumors }\end{array}$ & $\begin{array}{c}213 \\
(10.74)\end{array}$ & $\begin{array}{c}66 \\
(3.33)\end{array}$ & $\begin{array}{c}74 \\
(3.73)\end{array}$ & $\begin{array}{c}38 \\
(1.92)\end{array}$ & $\begin{array}{c}65 \\
(3.28)\end{array}$ & $\begin{array}{c}91 \\
(4.59)\end{array}$ & $\begin{array}{c}83 \\
(4.18)\end{array}$ & $\begin{array}{c}147 \\
(7.41)\end{array}$ & $\begin{array}{c}24 \\
(1.21)\end{array}$ & $\begin{array}{c}56 \\
(2.82)\end{array}$ \\
\hline $\begin{array}{l}\text { Melanocytic } \\
\text { tumors }\end{array}$ & $\begin{array}{c}46 \\
(2.32)\end{array}$ & $\begin{array}{c}1 \\
(0.05)\end{array}$ & $\begin{array}{c}5 \\
(0.25)\end{array}$ & $\begin{array}{c}6 \\
(0.30)\end{array}$ & $2(0.10)$ & $\begin{array}{c}23 \\
(1.16)\end{array}$ & $\begin{array}{c}5 \\
(0.25)\end{array}$ & $0(0.00)$ & $\begin{array}{c}1 \\
(0.05)\end{array}$ & $\begin{array}{c}5 \\
(0.25)\end{array}$ \\
\hline $\begin{array}{l}\text { Mesenchymal } \\
\text { tumors }\end{array}$ & $\begin{array}{c}39 \\
(1.97)\end{array}$ & $\begin{array}{c}29 \\
(1.46)\end{array}$ & $\begin{array}{c}39 \\
(1.97)\end{array}$ & $\begin{array}{c}77 \\
(3.88)\end{array}$ & $\begin{array}{c}97 \\
(4.89)\end{array}$ & $\begin{array}{c}65 \\
(3.28)\end{array}$ & $\begin{array}{c}52 \\
(2.62)\end{array}$ & $7(0.35)$ & $\begin{array}{c}7 \\
(0.35)\end{array}$ & $\begin{array}{c}25 \\
(1.26)\end{array}$ \\
\hline $\begin{array}{l}\text { Hematopoietic } \\
\text { tumors }\end{array}$ & $\begin{array}{c}101 \\
(5.09)\end{array}$ & $\begin{array}{c}36 \\
(1.81)\end{array}$ & $\begin{array}{c}32 \\
(1.61)\end{array}$ & $\begin{array}{c}84 \\
(4.23)\end{array}$ & $\begin{array}{c}85 \\
(4.28)\end{array}$ & $\begin{array}{c}111 \\
(5.59)\end{array}$ & $\begin{array}{c}85 \\
(4.28)\end{array}$ & $7(0.35)$ & $\begin{array}{c}3 \\
(0.15)\end{array}$ & $\begin{array}{c}52 \\
(2.62)\end{array}$ \\
\hline Total & $\begin{array}{c}399 \\
(20.11)\end{array}$ & $\begin{array}{c}132 \\
(6.65)\end{array}$ & $\begin{array}{c}150 \\
(7.56)\end{array}$ & $\begin{array}{c}205 \\
(10.33)\end{array}$ & $\begin{array}{c}249 \\
(12.55)\end{array}$ & $\begin{array}{c}290 \\
(14.62)\end{array}$ & $\begin{array}{c}225 \\
(11.34)\end{array}$ & $\begin{array}{c}161 \\
(8.11)\end{array}$ & $\begin{array}{c}35 \\
(1.76)\end{array}$ & $\begin{array}{c}138 \\
(6.96)\end{array}$ \\
\hline
\end{tabular}

Legend: NA - not available.

The prevalence of tumor types is shown in Table 3.

Table 3. Histological type, frequency, mean age, and sex ratio for canine cutaneous tumors

\begin{tabular}{|c|c|c|c|c|c|c|}
\hline \multirow[b]{2}{*}{ Tumor type } & \multirow[b]{2}{*}{$\mathbf{n}$} & \multirow{2}{*}{$\begin{array}{l}\% \text { of all } \\
\text { tumors }\end{array}$} & \multicolumn{2}{|l|}{ Age } & \multicolumn{2}{|c|}{ Sex } \\
\hline & & & $\begin{array}{c}\text { Mean age } \\
\text { (yrs) }\end{array}$ & NA & Male & Female \\
\hline Epithelial tumors & 857 & 43.20 & 7.79 & 11 & $518 *$ & $338 *$ \\
\hline Papilloma & 157 & 7.91 & 5.33 & 1 & 90 & 67 \\
\hline Squamous cell carcinoma & 146 & 7.36 & 7.48 & 1 & 85 & 61 \\
\hline Basosquamous carcinoma & 16 & 0.81 & 5.95 & 2 & 10 & 6 \\
\hline Basal cell tumor & 1 & 0.05 & 8.00 & & 1 & 0 \\
\hline Basal cell carcinoma & 22 & 1.11 & 8.09 & & 14 & 8 \\
\hline Infundibular keratinizing acanthoma & 10 & 0.50 & 7.50 & & 7 & 3 \\
\hline Tricholemmoma & 10 & 0.50 & 7.35 & & 3 & 7 \\
\hline Trichoblastoma & 88 & 4.44 & 7.42 & 2 & 48 & 40 \\
\hline Trichoepithelioma & 48 & 2.42 & 7.23 & 1 & 18 & 30 \\
\hline Pilomatricoma & 55 & 2.77 & 6.66 & 1 & 21 & 34 \\
\hline
\end{tabular}




\begin{tabular}{|c|c|c|c|c|c|c|}
\hline Malignant trichoepithelioma & 7 & 0.35 & 11.36 & & 2 & 5 \\
\hline Malignant pilomatricoma & 6 & 0.30 & 6.66 & & 1 & 5 \\
\hline Sebaceous adenoma & 65 & 3.28 & 9.74 & 1 & 37 & 28 \\
\hline Hepatoid adenoma & 87 & 4.39 & 10.09 & 1 & $73 *$ & $13^{*}$ \\
\hline Sebaceous epithelioma & 25 & 1.26 & 9.60 & & 15 & 10 \\
\hline Sebaceous adenocarcinoma & 32 & 1.61 & 9.25 & & 19 & 13 \\
\hline Hepatoid epithelioma & 43 & 2.17 & 9.44 & 1 & 41 & 2 \\
\hline Hepatoid adenocarcinoma & 13 & 0.66 & 10.58 & & 13 & 0 \\
\hline Apocrine adenoma & 5 & 0.25 & 12.00 & & 4 & 1 \\
\hline Apocrine adenocarcinoma & 8 & 0.40 & 10.12 & & 6 & 2 \\
\hline Eccrine adenoma & 9 & 0.45 & 6.72 & & 8 & 1 \\
\hline Eccrine adenocarcinoma & 4 & 0.20 & 8.00 & & 2 & 2 \\
\hline Melanocytic tumors & 94 & 4.74 & 8.08 & & 49 & 45 \\
\hline Melanocytoma & 10 & 0.50 & 7.55 & & 5 & 5 \\
\hline Melanoacanthoma & 1 & 0.05 & 5.50 & & 1 & 0 \\
\hline Malignant melanoma & 83 & 4.18 & 8.17 & & 43 & 40 \\
\hline Mesenchymal tumors & 437 & 22.03 & 8.10 & 4 & 227 & 210 \\
\hline Fibroma & 37 & 1.86 & 7.79 & 2 & 24 & 13 \\
\hline Myxoma & 19 & 0.96 & 9.37 & & 15 & 4 \\
\hline Fibrosarcoma & 68 & 3.43 & 8.61 & & 36 & 32 \\
\hline Myxosarcoma & 7 & 0.35 & 9.14 & & 4 & 3 \\
\hline Lipoma & 155 & 7.81 & 7.68 & 1 & 59 & 96 \\
\hline Liposarcoma & 26 & 1.31 & 7.12 & & 14 & 12 \\
\hline Hemangioma & 55 & 2.77 & 7.77 & 1 & 38 & 17 \\
\hline Hemangiosarcoma & 17 & 0.86 & 6.97 & & 9 & 8 \\
\hline Schwannoma & 24 & 1.21 & 9.31 & & 14 & 10 \\
\hline Malignant schwannoma & 16 & 0.81 & 9.75 & & 6 & 10 \\
\hline Hemangiopericytoma & 13 & 0.66 & 9.50 & & 8 & 5 \\
\hline Hematopoietic tumors & 596 & 30.04 & 5.93 & 15 & 333 & 263 \\
\hline Cutaneous mast cell tumor gr. 1 & 112 & 5.65 & 7.06 & 3 & 56 & 56 \\
\hline Cutaneous mast cell tumor gr. 2 & 107 & 5.39 & 7.94 & 2 & 54 & 53 \\
\hline Subcutaneous mast cell tumor & 125 & 6.30 & 8.08 & 2 & 62 & 63 \\
\hline Cutaneous histiocytoma & 194 & 9.78 & 2.32 & 7 & 124 & 70 \\
\hline Malignant histiocytoma & 25 & 1.26 & 7.31 & 1 & 20 & 5 \\
\hline Malignant fibrous histiocytoma & 7 & 0.35 & 7.86 & & 4 & 3 \\
\hline Cutaneous plasmacytoma & 7 & 0.35 & 8.71 & & 3 & 4 \\
\hline Epitheliotropic lymphoma & 1 & 0.05 & 3.50 & & 0 & 1 \\
\hline Non-epitheliotropic lymphoma & 18 & 0.91 & 6.53 & & 10 & 8 \\
\hline Total & 1984 & 100.00 & 7.32 & 30 & 1127 & 856 \\
\hline
\end{tabular}

Legend: *Sex for one dog is missing, NA - not available 


\section{Non-neoplastic cutaneous lesions}

In the examined period, a total of 448 non-neoplastic cutaneous lesions were diagnosed. The average age of dogs with these lesions was 6.17 years ( 6 months - 15 years), with $10(2.23 \%)$ dogs having no age data. Non-neoplastic cutaneous lesions were present in $250(55.80 \%)$ males and 198 (44.20\%) females. Total of 87 breeds were diagnosed with these lesions. As with tumors, one-fifth (90 dogs, 20.09\%) originated from mixed-breeds, followed by 29 (6.47\%) samples from American Staffordshire Terriers, 22 (4.91\%) from Labrador Retrievers, 19 (4.24\%) from German Shepherds, $17(3.79 \%)$ from Golden Retrievers and 14 (3.13\%) from Maltese. Non-neoplastic cutaneous lesions were most often localized on the head (88 samples, 19.64\%), followed by lesions from the forelimbs (70 samples, 15.63\%). In $61(13.62 \%)$ cases the biopsied samples were from the back, $54(12.05 \%)$ skin samples were taken from the skin of the hind limbs, $51(11.38 \%)$ samples were of the abdominal skin, $41(9.15 \%)$ from the chest skin, $25(5.58 \%)$ from the neck skin, $9(2.01 \%)$ from the tail skin and $6(1.34 \%)$ from the skin near the anus, while for $43(9.60 \%)$ dogs there were no localization data for the removed lesion.

Table 4. Histological type, frequency, mean age, and sex ratio for canine non-neoplastic cutaneous lesions

\begin{tabular}{lcccccc}
\hline \multirow{2}{*}{ Type of non-neoplastic lesion } & $\mathbf{n}$ & $\begin{array}{c}\text { \% of all non- } \\
\text { tumor lesions }\end{array}$ & $\begin{array}{c}\text { Age } \\
\text { Mean age } \\
\text { (yrs) }\end{array}$ & NA & Male & Female \\
\hline Folicullar cyst(s) & 157 & 35,04 & 6.57 & 3 & 71 & 86 \\
\hline Hyperkeratosis & 19 & 4,24 & 5.37 & & 11 & 8 \\
\hline Alopecia X & 17 & 3,79 & 3.53 & & 16 & 1 \\
\hline Calcinosis cutis & 15 & 3,35 & 7.07 & 1 & 9 & 6 \\
\hline Sebaceous adenitis & 6 & 1,34 & 4.83 & & 4 & 2 \\
\hline Demodicosis & 2 & 0,45 & 3.00 & & 1 & 1 \\
\hline Lipogranuloma & 1 & 0,22 & - & 1 & 1 & 0 \\
\hline Profound chronic dermatitis & 11 & 2,46 & 5.68 & & 8 & 3 \\
\hline Granulomatous dermatitis & 17 & 3,79 & 5.35 & 1 & 9 & 8 \\
\hline Mycotic granulomatous dermatitis & 2 & 0,45 & 6.00 & & 2 & 0 \\
\hline Pyogranulomatous chronic dermatitis & 107 & 23,88 & 6.40 & 1 & 65 & 42 \\
\hline Eosinophilic dermatitis & 12 & 2,68 & 5.63 & & 8 & 4 \\
\hline Lymphocytic dermatitis & 33 & 7,37 & 6.33 & & 15 & 18 \\
\hline Lymphohistiocytic dermatitis & 3 & 0,67 & 3.33 & & 2 & 1 \\
\hline Lymphoplasmacytic dermatitis & 13 & 2,90 & 6.71 & 1 & 8 & 5 \\
\hline Purulent dermatitis & 16 & 3,57 & 6.43 & 2 & 10 & 6 \\
\hline Apostematous dermatitis & 9 & 2,01 & 6.22 & & 6 & 3 \\
\hline Pustular dermatitis & 4 & 0,89 & 3.75 & & 2 & 2 \\
\hline Purulent-necrotic dermatitis & 3 & 0,67 & 7.33 & & 1 & 2 \\
\hline Profound necrotic dermatitis & 1 & 0,22 & 8.00 & & 1 & 0 \\
\hline Total & $\mathbf{4 4 8}$ & $\mathbf{1 0 0 . 0 0}$ & $\mathbf{6 . 1 7}$ & $\mathbf{1 0}$ & $\mathbf{2 5 0}$ & $\mathbf{1 9 8}$ \\
\hline & & & & & &
\end{tabular}

Legend: NA - not available. 
Detailed data on the frequency of non-neoplastic cutaneous lesions are shown in Table 4. As the table shows, slightly more than half (230 samples, 51.34\%) of nonneoplastic cutaneous lesions belongs to various forms of dermatitis.

\section{DISCUSSION}

During the 10.5-year examination period, almost half (48.63\%) of diagnosed lesions were of cutaneous origin. Of the total number of cutaneous lesions, $39.67 \%$ were tumors. This result is slightly lower compared to other reports where cutaneous tumors comprised about half of all tumors in dogs [2,3], but is higher compared to our previous studies $[4,18]$. The relatively high proportion of cutaneous lesions can be explained by the fact that the skin is an organ that is constantly exposed to various environmental factors and that neoplastic and non-neoplastic lesions are easily noticeable by the owner, as well during clinical examination and can be easily sampled. Compared to our previous studies, conducted from 1999 to mid-2004, it is noticeable that the average age of dogs with cutaneous neoplasms, sex distribution and ratio of malignant and benign tumors remained almost the same, but the average number of cutaneous neoplasms yearly increased by almost 5 times, from 38.36 in 2011 to 188.95 samples in 2021. Compared to the period 1999 - mid-2004, the total number of diagnosed tumor types also increased, so the number of epithelial and melanocytic tumor types increased from 17 to 25, mesenchymal tumors from 10 to 11 , and hematopoietic skin tumors from 5 to 9 . In addition, the prevalence of certain groups of tumors has changed, so the proportion of epithelial and melanocytic tumors decreased from $58.29 \%$ to $47.94 \%$, while the percentage of mesenchymal tumors increased from $19.43 \%$ to $22.03 \%$, as well as hematopoietic skin tumors from $22.27 \%$ to $30.04 \%$ [4,18]. Some authors [11] presented similar data on the prevalence of epithelial, mesenchymal and hematopoietic tumors $(27.97 \%, 29.85 \%$ and $22.02 \%$ respectively), but the proportion of melanocytic tumors is almost two times higher $(8.83 \%)$ compared to our results $(4.74 \%)$.

A slightly different distribution of cutaneous lesions is present in areas with a tropical climate (Grenada and the Caribbean region) where cutaneous tumors make up $72 \%$ of total skin biopsies. In these regions, cutaneous tumors often occur in mixed-breed dogs and most often are the following tumor types: hemangiosarcoma $19.1 \%$, histiocytoma $8.6 \%$, melanocytoma $8 \%$, mast cell tumor $6.8 \%$, lipoma $6.8 \%$, hemangiopericytoma $6.2 \%$, papilloma $5.6 \%$, fibrosarcoma $5.6 \%$, hemangioma $4.9 \%$, and squamous cell carcinoma $4.3 \%$ [5].

Melanocytic cutaneous tumors were found in $4.74 \%$ of the examined dogs, while $88.30 \%$ of all melanocytic tumors were malignant melanomas. However, the skin is not the only place where these tumors appear. According to the results of other authors [22], melanocytic skin tumors make up slightly more than half (59\%) of all melanocytic tumors in dogs. The authors point out that from all diagnosed melanocytic skin tumors, about $39 \%$ were malignant, but only $12 \%$ had malignant behavior. This 
percentage is almost two times lower than results of our study. In one study of melanocytic tumors [22], nuclear atypia is used as a significant indicator of malignancy, with $93.3 \%$ accuracy.

A more precise diagnosis of certain tumors, such as round cell tumors, requires additional histochemical staining methods, so we used toluidine-blue staining to confirm the diagnosis and to classify the mast cell tumors. In some cases, a more precise classification of round-cell skin tumors requires the use of antibody panels such as MHCII, CD18, Iba1, CD3, CD79a, CD20 and mast cell tryptase [23]. In our study, different forms of mast cell tumors were found in most cases. The high number of cases of mast cell tumors, variable behaviors of these tumors in dogs, and various histologic grading systems have a great impact on prognosis. Prognostic determination of the mast cell tumor depends on the tumor grade, but sometimes is necessary to determine the KIT receptor expression and presence of c-KIT proto-oncogene mutations in neoplastic cells. Our previous studies showed that $58.33 \%$ of mast cell tumors in dogs were of a high histologic grade, and $41.43 \%$ were classified as a lowgrade malignancy. The expression of CD117 in cytoplasm was observed in $64.29 \%$ of high-grade malignancy mast cell tumors, while mutations of c-KIT proto-oncogene were not found in tumor samples from dogs with mast cell tumor [24,25]. Roundcell tumors are among the most common cutaneous tumors, and the established distribution of mast cell tumor, histiocytoma and lymphoma are close to the results presented by other authors [26].

Some cutaneous tumors occur in a smaller percentage. Thus, schwannomas were found in $1.21 \%$ and hemangiopericytomas in $0.66 \%$ of cases. In contrast to our results, Graf et al. (2018) report a slightly higher proportion of perivascular wall tumor $(4.57 \%)$, but a lower prevalence of peripheral nerve sheath tumor $(0.09 \%)$ [11]. In some cases, due to a similar histologic pattern, the differentiation between these two tumor types requires certain antibodies for immunohistochemistry [27].

Although only $19(0.96 \%)$ tumors of the total number of reported cases were cutaneous lymphomas, these types of tumors are very important in clinical oncology. In addition to diagnosing cutaneous lymphomas, other parameters, such as tumor cell immunophenotype and neoplastic lesion distribution, need to be considered for an accurate prognosis. Ninety percent of cutaneous epitheliotropic lymphomas develop in the form of multiple cutaneous lesions, which significantly reduce the length of survival of dogs to 104 days (compared to 231 days in case of solitary lesions). Slightly more than half $(54 \%)$ of epitheliotropic lymphomas are cutaneous lymphomas, of which 62.5\% occur in females [28]. Cutaneous epitheliotropic T-cell lymphomas are significant, especially from the aspect of clinical dermatopathology, manifesting as diffuse erythema with scaling and focal hypopigmentation [29]. However, the exact prevalence of different immunophenotypes of cutaneous lymphomas in our study is not known, since detailed immunophenotyping of tumor cells hasn't been performed in all samples. 
Most cutaneous lesion specimens came from mixed breeds, Labrador Retrievers, Golden Retrievers, American Staffordshire Terriers and Bichons. The prevalence of certain breeds depends on the presence of breeds in the study area, so Greek authors [6] most often notice skin tumors in dogs such as German Shepherd, Miniature Poodle, Greek Hound and English Pointer, and Kok et al. (2019) [7] indicate that cutaneous lesions are most common in mixed-breed dogs and Miniature Dachshund. The occurrence of a large number of tumors in mixed breed dogs, retrievers and American Staffordshire Terriers could be a consequence of the large number of these dogs in the dog population.

In general, the appearance of tumors is characteristic of older dogs. The average age of dogs with cutaneous neoplasms is 7.32 years, with malignant tumors occurring primarily in older dogs (mean age 8.03 years) and benign in dogs of average age 6.66 years. A study of cutaneous neoplasms in dogs in Brazil, over a period of 10 years, showed that the largest number of tumors occurs in dogs between the ages of 9 and 11 [30]. Non-cutaneous lesions are most often diagnosed in dogs with an average age of 6.57 years.

Various forms of dermatitis are found to be the most common non-neoplastic cutaneous lesions in dogs, which make up slightly more than half of all non-neoplastic cutaneous lesions. Contrary to these results, in tropical climates, various forms of canine dermatitis make up only $12.4 \%$ of all cutaneous lesions of which half $(50 \%)$ are pyogranulomatous dermatitis, a quarter (25\%) different forms of chronic dermatitis, $10.7 \%$ purulent dermatitis, as much sterile granuloma and $3.6 \%$ allergic dermatitis [5].

In summary, our results substantially confirm previously reported data regarding cutaneous neoplastic and non-neoplastic lesions in dogs, and provide updated information on the most common cutaneous lesions, animal age, anatomic location and breed distributions.

\section{Acknowledgement}

The study was supported by the Ministry of Education, Science and Technological Development of the Republic of Serbia (Contract number 451-03-68/202014/200143). We appreciate colleagues Dr. Ivana Vučićević and Dr. Milan Aničić for language corrections and critically reading the manuscript.

\section{Authors' contributions}

VK and SAK conceived and designed the study, made substantial contributions to the writing of manuscript and critically revised the manuscript. VK, SN and DM were responsible for data collection, performed the statistical analysis and made substantial contributions to interpretation of data. All authors read and approved the final manuscript. 


\section{Declaration of conflicting interests}

The author(s) declared no potential conflicts of interest with respect to the research, authorship, and/or publication of this article.

\section{REFERENCES}

1. Dennis MM, McSporran KD, Bacon NJ, Schulman FY, Foster RA, Powers BE: Prognostic factors for cutaneous and subcutaneous soft tissue sarcomas in dogs. Vet Pathol 2011, 48(1):73-84.

2. Šoštarić-Zuckermann IC, Severin K, Hohšteter M, Artuković B, Beck A, Gudan Kurilj A, Sabočanec R, Džaja P, Grabarević Ź: Incidence and types of canine tumours in Croatia. Vet Arh 2013, 83(1):31-45.

3. de Araújo Viana D, de Farias KM, Lopes CEB, Miranda AM, Pacheco ACL, Souza LP, de Oliveira DM, da Silva LDM: Retrospective survey of neoplastic disease in dogs. Rev Bras Hig Sanid Anim 2019, 13(3):348-367.

4. Aleksić-Kovačević S, Kukolj V, Marinković D, Knežević M: Retrospective study of canine epithelial and melanocytic tumors. Acta Vet - Beograd 2005, 55(4):319-326.

5. Chikweto A, McNeil P, Bhaiyat MI, Stone D, Sharma RN: Neoplastic and nonneoplastic cutaneous tumors of dogs in Grenada, West Indies. ISRN Vet Sci 2011, 2011:416435.

6. Kaldrymidou H, Leontides L, Koutinas AF, Saridomichelakis MN, Karayannopoulou M: Prevalence, distribution and factors associated with the presence and the potential for malignancy of cutaneous neoplasms in 174 dogs admitted to a clinic in northern Greece. J Vet Med A Physiol Pathol Clin Med 2002, 49(2):87-91.

7. Kok MK, Chambers JK, Tsuboi M, Nishimura R, Tsujimoto H, Uchida K, Nakayama H: Retrospective study of canine cutaneous tumors in Japan, 2008-2017. J Vet Med Sci 2019, 81(8):1133-1143.

8. Machado GAC, Fontes TN, Larangeira DF, Estrela-Lima A, Moreira ELT, Ribeiro MS, Pinto MRP, Peixoto TC: Incidence of skin tumors in dogs in Salvador, Bahia state, Brazil (2007-2016). Pesq Vet Bras 2018, 38(11):2139-2145.

9. Vučićević I, Marinković D, Kukolj V, Nešić S, Aničić M, Aleksić-Kovačević S: Mast cell tumor within a benign lipoma in a toy poodle. Veterinarski Glasnik 2018, 72(1):64-67. doi: 10.2298/VETGL170611002V

10. Pakhrin B, Kang MS, Bae IH, Park MS, Jee H, You MH, Kim JH, Yoon BI, Choi YK, Kim DY: Retrospective study of canine cutaneous tumors in Korea. J Vet Sci 2007, 8(3):229-236.

11. Graf R, Pospischil A, Guscetti F, Meier D, Welle M, Dettwiler M: Cutaneous tumors in Swiss dogs: retrospective data from the Swiss Canine Cancer Registry, 2008-2013. Vet Pathol 2018, 55(6):809-820.

12. Tompkins S, Fosgate GT, Williams J, Clift S: Breed and anatomical predisposition for canine cutaneous neoplasia in South Africa during 2013. Vet Rec 2020;186(7):218.

13. Villamil JA, Henry CJ, Bryan JN, Ellersieck M, Schultz L, Tyler JW, Hahn AW: Identification of the most common cutaneous neoplasms in dogs and evaluation of breed and age distributions for selected neoplasms. J Am Vet Med Assoc 2011, 239(7):960-965.

14. Nikula KJ, Benjamin SA, Angleton GM, Saunders WJ, Lee AC: Ultraviolet radiation, solar dermatosis, and cutaneous neoplasia in beagle dogs. Radiat Res 1992, 129(1):11-18. 
15. Šimkus D, Pockevičius A, Mačiulskis P, Šimkienè V, Zorgevica-Pockeviča L: Pathomorphological analysis of the most common canine skin and mammary tumours. Vet Med Zoot 2015, 69(91):63-70.

16. Fulmer AK, Mauldin GE: Canine histiocytic neoplasia: an overview. Can Vet J 2007, 48(10):1041-1050.

17. Lakatos I, Baba AI, Catoi C, Gal AF, Rus IV, Kinga K: Spontaneous skin tumors in dogs and cats, squamous carcinoma. Bull Univ Agric Sci Vet Med 2008, 65(1):51-54.

18. Aleksić-Kovačević S, Kukolj V, Jelesijević T, Jovanović M: Retrospective analysis of canine mesenchymal tumors of skin and soft tissues. Acta Vet - Beograd 2005, 55(5-6):521-529.

19. Goldschmidt MH, Dunstan RW, Stannard AA, von Tscharner C, Walder EJ, Yager JA: WHO international classification of tumors of domestic animals - Histological classification of epithelial and melanocytic tumors of skin and soft tissues of domestic animals. Second series, Volume III. Washington DC, USA: Armed Forces Institute of Pathology; 1998.

20. Hendrick MJ, Mahaffey EA, Moore FM, Vos JH, Walder EJ: WHO international classification of tumors of domestic animals - Histological classification of mesenchymal tumors of skin and soft tissues of domestic animals. Second series, Volume II. Washington DC, USA: Armed Forces Institute of Pathology; 1998.

21. Goldschmidt MH, Munday JS, Scruggs JL, Klopfleisch R, Kiupel M: Surgical pathology of tumors of domestic animals: Volume 1. Epithelial tumors of the skin. Illinois, USA: DavisThompson Foundation; 2018.

22. Spangler WL, Kass PH: The histologic and epidemiologic bases for prognostic considerations in canine melanocytic neoplasia. Vet Pathol 2006, 43(2):136-149.

23. Pazdzior-Czapula K, Mikiewicz M, Gesek M, Zwolinski C, Otrocka-Domagala I: Diagnostic immunohistochemistry for canine cutaneous round cell tumours - retrospective analysis of 60 cases. Folia Histochem Cytobiol 2019, 57(3):146-154.

24. Marinković D, Milčić-Matić N, Jovanović M, Vučićević I, Nešić S, Aničić M, AleksićKovačević S: Morphological features and KIT receptor expression in canine cutaneous mast cell tumor and systemic mastocytosis. Acta Vet - Beograd 2015, 65(2):226-237.

25. Vučićević I, Marinković D, Kukolj V, Vučićević M, Mirilović M, Nešić S, AleksićKovačević S: KIT receptor expression in canine cutaneous mast cell tumors (CMCTs) without c-KIT mutation. Acta Vet - Beograd 2016, 66(2):222-233.

26. Cora R, Gal AF, Taulescu M, Tabaran F, Nagy A, Negru M, Catoi C: Epidemiological aspects and differential diagnosis of the cutaneous round cell tumors in dogs. Bull Univ Agric Sci Vet Med 2017, 74(1):64-70.

27. Vučićević I, Marinković D, Kukolj V, Nešić S, Aničić M, Đurđević B, Aleksić-Kovačević S: Immunohistochemical distinguishing between canine peripheral nerve sheath tumors and perivascular wall tumors. Acta Vet - Beograd 2019, 69(3):290-299.

28. Chan CM, Frimberger AE, Moore AS: Clinical outcome and prognosis of dogs with histopathological features consistent with epitheliotropic lymphoma: a retrospective study of 148 cases (2003-2015). Vet Dermatol 2018, 29(2):154-e59.

29. Fontaine J, Heimann M, Day MJ: Canine cutaneous epitheliotropic T-cell lymphoma: a review of 30 cases. Vet Dermatol 2010, 21(3):267-275.

30. Morales JRE, Baretta DC, Zanetti AS, Garrido E, Miyazato LG, Sevarolli AL: Cutaneous tumors in dogs - a retrospective study of ten years. Vet Not 2009, 15(1):59-68. 


\title{
PREVALENCA I DISTRIBUCIJA NEOPLASTIČNIH \\ I NENEOPLASTIČNIH LEZIJA KOŽE KOD PASA U SRBIJI: RETROSPEKTIVNA STUDIJA 2432 SLUČAJA (2011 - SREDINA 2021)
}

\author{
Vladimir KUKOLJ, Slađan NEŠIĆ, Darko MARINKOVIĆ, \\ Sanja ALEKSIĆ-KOVAČEVIĆ
}

Kožne lezije kod pasa, naročito tumori, spadaju među najčešće lezije kod ove životinjske vrste. Cilj ovog istraživanja bio je da se identifikuju najčešći tipovi kožnih lezija kod pasa, kao i da se utvrde apsolutna i relativna učestalost svake vrste kožnih lezija, anatomska lokacija, prosečna starost, kao i rasna i polna distribucija. Ispitivanjem su obuhvaćeni svi uzorci lezija kože kod pasa koji su dobijeni hirurškom biopsijom u veterinarskim ambulantama i pregledani u laboratoriji Katedre za patologiju Fakulteta veterinarske medicine Univerziteta u Beogradu u periodu od 1. januara 2011. do 1. jula 2021. godine. U ovom periodu od 126 meseci, pregledana su ukupno 2432 uzorka kožnih lezija, od čega su 1984 (81,58\%) bili tumori $(1037 / 1984,52,27 \%$ benigni i $947 / 1984,47,73 \%$ maligni) i 448 (18,42\%) neneoplastične lezije kože. Najčešći tumori kože bili su: mastocitom (17,34\% svih tumora), histiocitom $(9,78 \%)$, papilom $(7,91 \%)$, lipom $(7,81 \%)$, planocelularni karcinom $(7,36 \%)$, trihoblastom $(4,44 \%)$, adenom hepatoidne žlezde $(4,39 \%)$ i maligni melanom (4,18\%). Najčešće neneoplastične lezije kože bile su: folikularne ciste (35,04\% svih neneoplastičnih lezija), hronični piogranulomatozni dermatitis $(23,88 \%)$, limfocitni dermatitis $(7,37 \%)$, hiperkeratoza $(4,24 \%)$ i granulomatozni dermatitis $(3,79 \%)$. Naši rezultati u velikoj meri potvrđuju ranije objavljene podatke o neoplastičnim i neneoplastičnim lezijama kože kod pasa i pružaju nove ažurirane informacije o njihovoj učestalosti, starosti životinje, anatomskoj lokaciji i rasnoj i polnoj distribuciji. 